\title{
Peningkatan Indeks Pertanaman Padi pada Musim Tanam ke Dua di Kecamatan Ngawen, Kabupaten Gunungkidul, Provinsi Daerah Istimewa Yogyakarta
}

\author{
Arif Anshori *, Damasus Riyanto dan Suradal \\ Balai Pengkajian Teknologi Pertanian Yogyakarta, Indonesia
}

Diterima: 29 Juni 2020; Disetujui: 21 Oktober 2020

\begin{abstract}
Abstrak
Peningkatan produksi padi melalui perluasan areal sudah sangat sulit dilakukan di Kabupaten Gunungkidul. Peningkatan indeks pertanaman padi merupakan alternatif pilihan dalam peningkatan produksi padi, didukung irigasi tambahan. Penelitian ini bertujuan mengetahui peningkatan indeks pertanaman padi 1 menjadi 2 dengan memanfaatkan irigasi tambahan asal Bendung Sungai Oyo. Penelitian dilaksanakan di Sambirejo, Watusigar, Ngawen, Gunungkidul, Daerah Istimewa Yogyakarta pada musim tanam ke dua tahun 2019. Selama waktu tanam, curah hujan diamati untuk menentukan waktu penyiraman. Pada kondisi tanpa hujan, interval penyiraman tidak lebih dari 5 hari. Rancangan Acak Kelompok Lengkap (RAKL) digunakan untuk mengetahui kesesuaian varietas Inpari 19, Inpari 24, Inpari 30, Inpari 42 dan Sidenuk pada kondisi musim tanam ke dua, lengkap dengan paket komponen teknologi produksi padi. Data yang dikumpulkan meliputi curah hujan, umur panen dan produktivitas padi. Persepsi petani digali untuk mengetahui penerimaan terhadap komponen teknologi. Hasil penelitian menunjukkan irigasi tambahan asal Bendung Sungai Oyo cukup untuk peningkatan indeks pertanaman padi pada musim tanam ke dua. Varietas Inpari 24, Inpari 19 dan Inpari 30 memiliki produktivitas tinggi, dengan Inpari 19 prospektif dikembangkan untuk pertanaman padi pada musim tanam ke dua. Sebagian besar petani menerima paket komponen teknologi, namun terkendala modal untuk penyiraman.
\end{abstract}

Kata kunci: musim tanam ke dua; padi; varietas unggul

\section{The Increase of Rice Cropping Index in the Second Planting Season at Ngawen Sub-district,} Gunungkidul Regency, Special region of Yogyakarta

\begin{abstract}
Increasing rice production through area expansion is very difficult to do in Gunungkidul Regency. Increasing the rice cropping index is an alternative option in increasing rice production, supported by supplementary irrigation. This study aimed to determine the increase in the rice cropping index from 1 to 2 by utilizing supplementary irrigation from the Oyo River Dam. The research was conducted at Sambirejo, Watusigar Village, Ngawen Sub-district, Gunungkidul Regency, Special Region of Yogyakarta during the second planting season in 2019. During planting time, rainfall was observed to determine irrigation time. In conditions without rain, the irrigation interval was not more than 5 days. The randomized completely block design $(R C B D)$ was used to determine the suitability variety of Inpari 19, Inpari 24, Inpari 30, Inpari 42 and Sidenuk in the conditions of the second planting season, complete
\end{abstract}

\footnotetext{
* Corresponding author: arifanshori@yahoo.com

Cite this as: Anshori, A., Riyanto, D., \& Suradal. (2020). Peningkatan Indeks Pertanaman Padi pada Musim Tanam ke Dua di Kecamatan Ngawen, Kabupaten Gunungkidul, Provinsi Daerah Istimewa Yogyakarta. AgriHealth: Journal of Agri-food, Nutrition and Public Health, 1(2), 55-61. doi: http://dx.doi.org/10.20961/ agrihealth.v1i2.42481
} 
with a package of rice production technology components. The data collected includes rainfall, harvest age and rice productivity. Farmers' perceptions was explored to determine acceptance of technology components. The results showed that supplementary irrigation from the Oyo River Dam was sufficient to increase the rice planting index in the second planting season. Variety of Inpari 24, Inpari 19 and Inpari 30 had high productivity, with Inpari 19 being prospectively developed for rice cultivation in the second planting season. Most farmers receive a package of technology components, but were constrained by capital for irrigation.

Keywords: rice; second planting season; superior variety

\section{PENDAHULUAN}

Padi merupakan komoditas strategis ditinjau dari aspek ekonomi, sosial dan politik (Makarim et al., 2007). Keamanan dan kecukupan pangan, terutama beras, merupakan tolok ukur dalam pengambilan kebijakan (Alimoeso, 2009). Kebutuhan beras sebagai makanan pokok semakin tinggi (Makarim et al., 2007; Hutajulu et al., 2013) sejalan dengan kenaikan jumlah penduduk (Makarim et al., 2007).

Strategi peningkatan produksi padi dapat dilakukan melalui peningkatan produktivitas padi, perluasan areal padi sawah dan pengelolaan lahan (Las et al., 2004). Peningkatan produksi padi hingga swasembada pada tahun 1984 ditempuh melalui beberapa cara, yaitu peningkatan indeks pertanaman, peningkatan produktivitas, penekanan kehilangan hasil dan perluasan areal. Peningkatan produktivitas berkontribusi 57\%, kemudian peningkatan indeks pertanaman 37\% dan penekanan kehilangan hasil 5\% (Las et al., 1999).

Luas lahan pertanian di Kabupaten Gunungkidul 83.166 ha, sebagian besar berupa lahan tegal/kebun mencapai 65.713 ha $(79,01 \%)$, sawah irigasi 2.189 ha $(2,63 \%)$ dan sawah non irigasi 5.674 ha $(6,82 \%)$ (BPS Kabupaten Gunungkidul, 2018). Sangat sulit untuk menambah luas areal lahan pertanian untuk tanaman padi di Kabupaten Gunungkidul. Salah satu cara meningkatkan produksi padi di Kabupaten Gunungkidul dapat ditempuh melalui peningkatan indeks pertanaman padi.

Pada lahan sawah tadah hujan dan tegal/kebun di Kabupaten Gunungkidul, padi biasa ditanam pada musim tanam pertama atau saat awal musim hujan. Peningkatan indeks pertanaman padi dapat dilakukan pada musim tanam ke dua memanfaatkan curah hujan yang masih ada dan tambahan irigasi dari pompa air sumur dalam, sumur dangkal, air sungai atau dam parit. Varietas unggul dan komponen teknologi produksi padi yang sesuai dengan karakteristik lokasi akan mendukung keberhasilan peningkatan indeks pertanaman padi pada musim tanam ke dua.

Penanaman varietas unggul berdaya hasil tinggi sangat diandalkan dalam peningkatan produktivitas (Suprihatno et al., 2007; Nurhati et al., 2008). Penggunaan varietas unggul bersifat mudah dan murah, karena dapat dilakukan tanpa mengubah komponen teknologi lainnya serta tidak memerlukan tambahan biaya (Guswara dan Samaullah, 2009), serta mudah diadopsi oleh petani (Soewito et al., 1995; Daradjat, 2 001). Varietas unggul berperan penting dalam peningkatan kuantitas dan kualitas produk pertanian (Suyamto et al., 2007). Varietas unggul memberikan kontribusi 56,1\% pada peningkatan produksi padi nasional (Balai Penelitian Tanaman Padi, 2004), lebih tinggi dari pada perluasan areal lahan yang sebesar 26,3\% (Las et al., 2004). Kriteria penting lain varietas unggul adalah potensi hasil tinggi, ketahanan terhadap hama dan penyakit utama, tekstur dan rasa (Suprihatno et al., 2007).

Beragam varietas unggul menjadi alternatif bagi petani sesuai dengan kondisi agroklimat (Minarsih et al., 2013). Namun, potensi maksimal varietas unggul baru tercapai pada kondisi lingkungan tumbuh yang sesuai (Makarim dan Las, 2005). Selain faktor genetik, hasil juga ditentukan oleh faktor lingkungan (Sadikin, 1985). Produktivitas merupakan salah satu indikator tingkat adaptasi varietas (Saidah et al., 2015).

Pemerintah Kabupaten Gunungkidul telah banyak membangun sarana irigasi berupa sumur tanah dalam, sumur tanah dangkal, bendung sungai, dam parit maupun embung untuk pengembangan pertanian. Salah satunya adalah irigasi Bendung Sungai Oyo di Dusun Sambirejo, Desa Watusigar, Kecamatan Ngawen, Kabupaten Gunungkidul yang dibangun pada tahun 2018. 
Sarana irigasi ini baru dimanfaatkan pada musim tanam pertama pada awal tahun 2019. Pada musim tanam ke dua tahun 2019, sarana irigasi dimanfaatkan untuk mendukung peningkatan indeks pertanaman padi. Pada musim tanam ke dua tahun sebelumnya, petani biasa menanam palawija atau sayuran. Penelitian ini bertujuan untuk mengetahui peningkatan indeks pertanaman padi 1 menjadi 2 pada musim tanam ke dua dengan memanfaatkan irigasi tambahan asal Bendung Sungai Oyo.

\section{BAHAN DAN METODE}

Penelitian untuk mengetahui peningkatan indeks pertanaman padi dari 1 menjadi 2 pada musim tanam ke dua dilaksanakan di Dusun Sambirejo, Desa Watusigar, Kecamatan Ngawen,
Kabupaten Gunungkidul, Daerah Istimewa Yogyakarta. Lokasi berada pada $7^{\circ} 52^{\prime} 2$ " LS, $110^{\circ} 41^{\prime} 36^{\prime \prime}$ BT, dengan ketinggian tempat $196 \mathrm{~m}$ dpl (meter di atas permukaan laut). Penelitian dilaksanakan pada bulan Maret - Juli 2019. Pada musim tanam ke dua, petani biasa menanam jagung/kacang tanah/kacang hijau/kedelai/ sayuran. Pada musim tanam kedua tahun 2019, petani meningkatkan indeks pertanaman padi dengan memanfaatkan irigasi tambahan asal Bendung Sungai Oyo yang baru dibangun pada tahun 2018. Varietas unggul padi yang digunakan adalah Inpari 19, Inpari 24, Inpari 30, Inpari 42 dan Sidenuk. Komponen teknologi yang diterapkan pada peningkatan indeks pertanaman padi pada musim tanam ke dua dapat dilihat pada Tabel 1 .

Tabel 1. Komponen teknologi yang diterapkan pada pertanaman padi

\begin{tabular}{ll}
\hline \multicolumn{1}{c}{ Komponen teknologi } & \multicolumn{1}{c}{ Keterangan } \\
\hline Varietas unggul & Inpari 19, Inpari 24, Inpari 30, Inpari 42, Sidenuk \\
Benih & Berlabel \\
Bibit & Kurang dari 20 hari setelah sebar \\
Jarak tanam & Jajar legowo 2:1; 2-3 bibit per lubang \\
Olah tanah & Mekanisasi traktor roda 2 \\
Pemupukan & Urea 100 $\mathrm{kg} \mathrm{ha}^{-1}$, NPK 200 $\mathrm{kg} \mathrm{ha}^{-1}$ \\
Pengairan & Berselang; sumber air hujan dan memanfaatkan irigasi pompa air sungai \\
Pengendalian OPT & Terpadu \\
Panen & Mekanisasi pedal thresher \\
\hline
\end{tabular}

Tiap varietas diulang sebanyak tiga kali, menggunakan lahan atau petak petani yang berbeda, sehingga berbentuk Rancangan Acak Kelompok Lengkap (RAKL) dengan 5 perlakuan dan 3 ulangan. Produktivitas padi dihitung berdasarkan berat gabah kering panen dari hasil ubinan 2,5 x 2,5 m. Data curah hujan diperoleh dari Balai Penyuluhan Pertanian Kecamatan Ngawen Kabupaten Gunungkidul. Wawancara dilakukan terhadap 20 orang petani untuk mengetahui persepsi petani terhadap komponen teknologi pada peningkatan indeks pertanaman padi pada musim tanam ke dua. Produktivitas padi diuji beda nyata taraf $5 \%$.

\section{HASIL DAN PEMBAHASAN}

Iklim mempengaruhi pola dan waktu tanam. Pilihan komoditas dan waktu tanam menentukan keberhasilan usaha tani, termasuk padi, terutama untuk daerah tadah hujan. Cekaman kekeringan menjadi ancaman saat ketersediaan air dari curah hujan tidak mencukupi. Ketidaktepatan waktu tanam padi dapat menurunkan hasil atau bahkan kegagalan panen.

Petani Dusun Sambirejo, Desa Watusigar, Kecamatan Ngawen, Kabupaten Gunungkidul, pada lahan tadah hujan biasa menanam padi pada musim tanam pertama saat mulai musim hujan. Petani menanam padi mengandalkan ketersediaan air dari curah hujan. Pada musim tanam ke dua petani menanam palawija atau sayuran.

Sarana irigasi pompa asal Bendung Sungai Oyo dibangun tahun 2018 memungkinkan petani memperoleh tambahan air irigasi. Sarana ini dimanfaatkan petani untuk meningkatkan indeks pertanaman padi pada musim tanam ke dua. Curah hujan pada musim tanam padi ke dua sebesar 356 mm. Hujan terjadi pada bulan Maret Dasarian III sampai bulan Mei Dasarian I. Kekurangan air dari curah hujan dicukupi dengan irigasi pompa asal Bendung Sungai Oyo. Upaya peningkatan indeks pertanaman padi 1 menjadi 2 pada musim tanam ke dua dengan memanfaatkan irigasi tambahan asal Bendung Sungai Oyo dapat dilakukan. 
Komponen teknologi produksi peningkatan indeks pertanaman padi pada musim tanam ke dua tertera dalam Tabel 1. Varietas unggul padi yang digunakan adalah Inpari 19, Inpari 24, Inpari 30, Inpari 42 dan Sidenuk, dengan benih yang berlabel. Tanam bibit kurang dari 20 hari setelah sebar, 2-3 bibit per lubang tanam, secara jajar legowo 2:1. Olah tanah dengan traktor roda 2. Pemupukan $100 \mathrm{~kg}$ urea dan $200 \mathrm{~kg}$ NPK. Pengairan berselang memanfaatkan curah hujan yang masih turun dengan tambahan irigasi pompa dari Bendung Sungai Oyo.
Pengendalian gulma, hama dan penyakit secara terpadu. Panen menggunakan pedal thresher.

Kenampakan tanaman padi menjelang panen dapat dilihat pada Gambar 1. Inpari 19 dan Sidenuk dipanen saat 81 hari setelah tanam (HST), Inpari 42 dipanen saat umur 85 HST, serta Inpari 24 dan Inpari 30 dipanen saat umur 86 HST. Cuaca panas dan hari tanpa hujan sejak dasarian II bulan Mei diduga mempercepat pemasakan butir padi, sehingga umur panen padi menjadi pendek dan panen dilakukan lebih cepat.

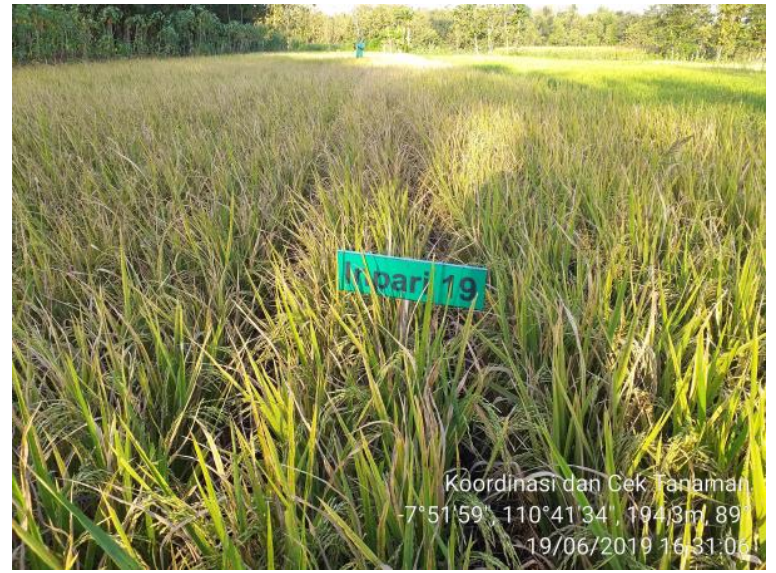

a.

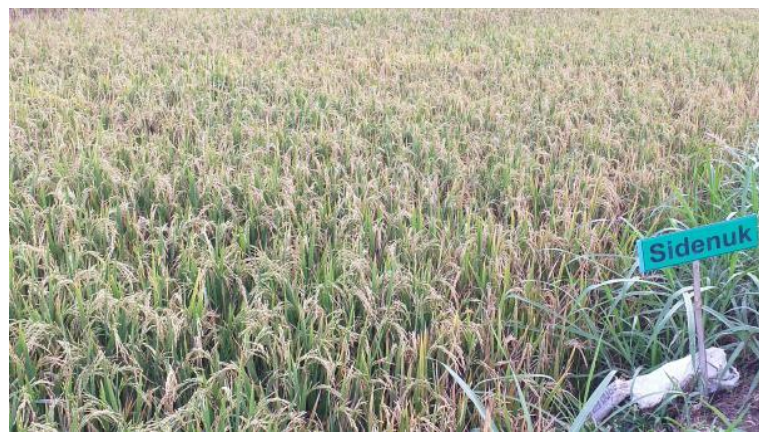

c.

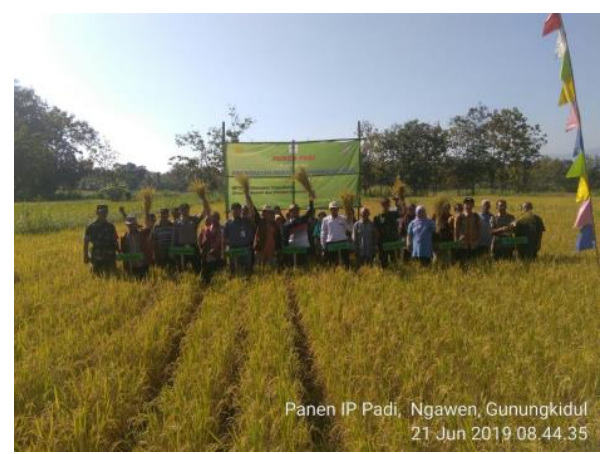

e.

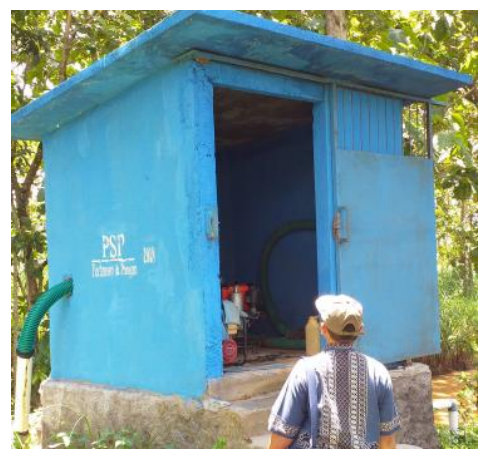

f.

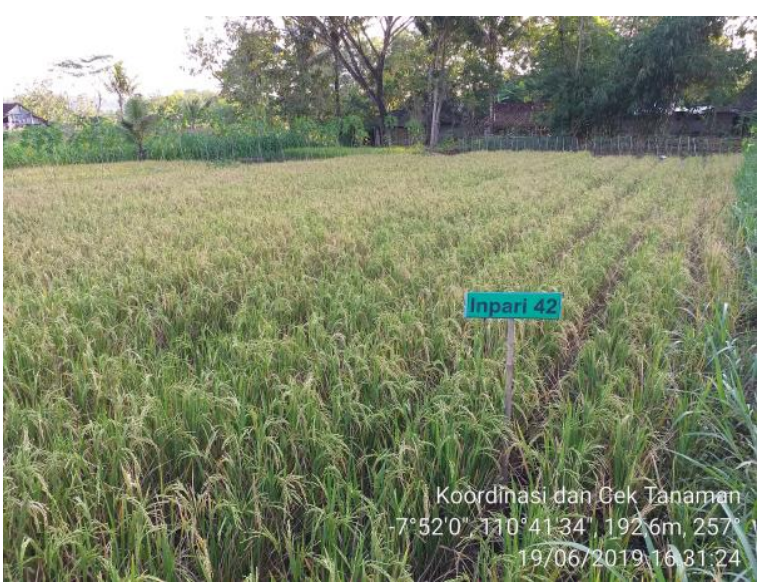

b.

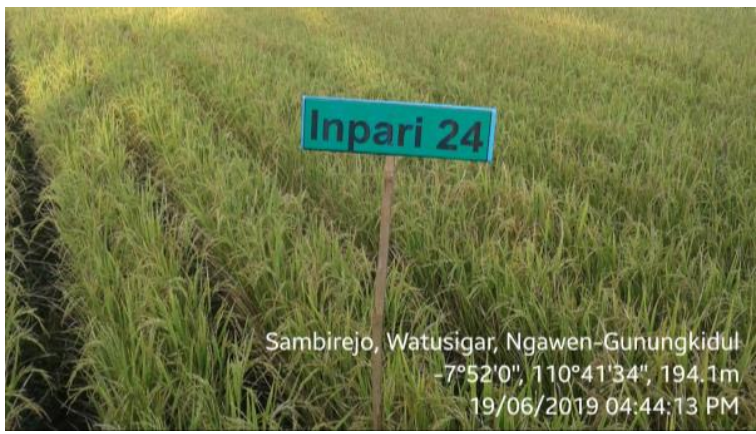

d.

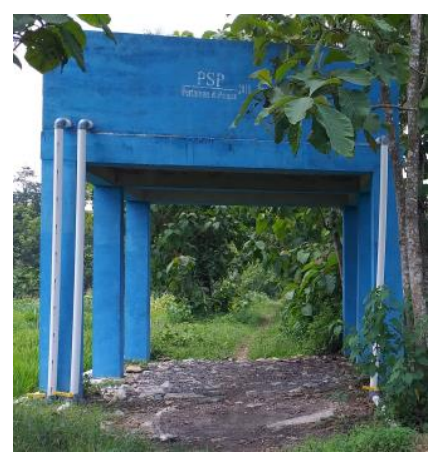

g.

Gambar 1. Tanaman padi varietas Inpari 19 (a), Inpari 42 (b), Sidenuk (c), Inpari 24 (d), panen raya padi (e) dan pompa air (f) serta bak penampung lengkap dengan saluran distribusi air (g) 
Produktivitas padi dapat dilihat pada Gambar 2. Inpari 42 menghasilkan produktivitas tertinggi $\left(5,4\right.$ ton $\left.\mathrm{ha}^{-1}\right)$, tidak berbeda nyata dengan Inpari $19\left(5,3\right.$ ton ha $\left.^{-1}\right)$ dan Inpari $30(5,2$ ton $\left.\mathrm{ha}^{-1}\right)$. Inpari 24 menghasilkan produktivitas terendah $\left(3,8\right.$ ton $\left.\mathrm{ha}^{-1}\right)$ dan berbeda nyata taraf 5\% dengan semua varietas yang lain. Padi varietas Sidenuk menghasilkan produktivitas terendah ke dua $\left(4,2\right.$ ton $\left.\mathrm{ha}^{-1}\right)$ dan berbeda secara nyata taraf $5 \%$ dengan semua varietas yang lain.
Varietas Inpari 30, Inpari 19 dan Inpari 42 menghasilkan produktivitas tinggi, namun berbeda umur panen. Inpari 19 mempunyai umur panen terpendek (81 HST). Inpari 19 dapat menjadi alternatif pilihan untuk pertanaman padi pada musim tanam ke dua, karena produktivitas tinggi dan panen lebih cepat. Panen lebih cepat penting sebagai bahan pertimbangan untuk mengurangi resiko akibat kekeringan. Sidenuk berumur pendek, namun produktivitas lebih rendah.

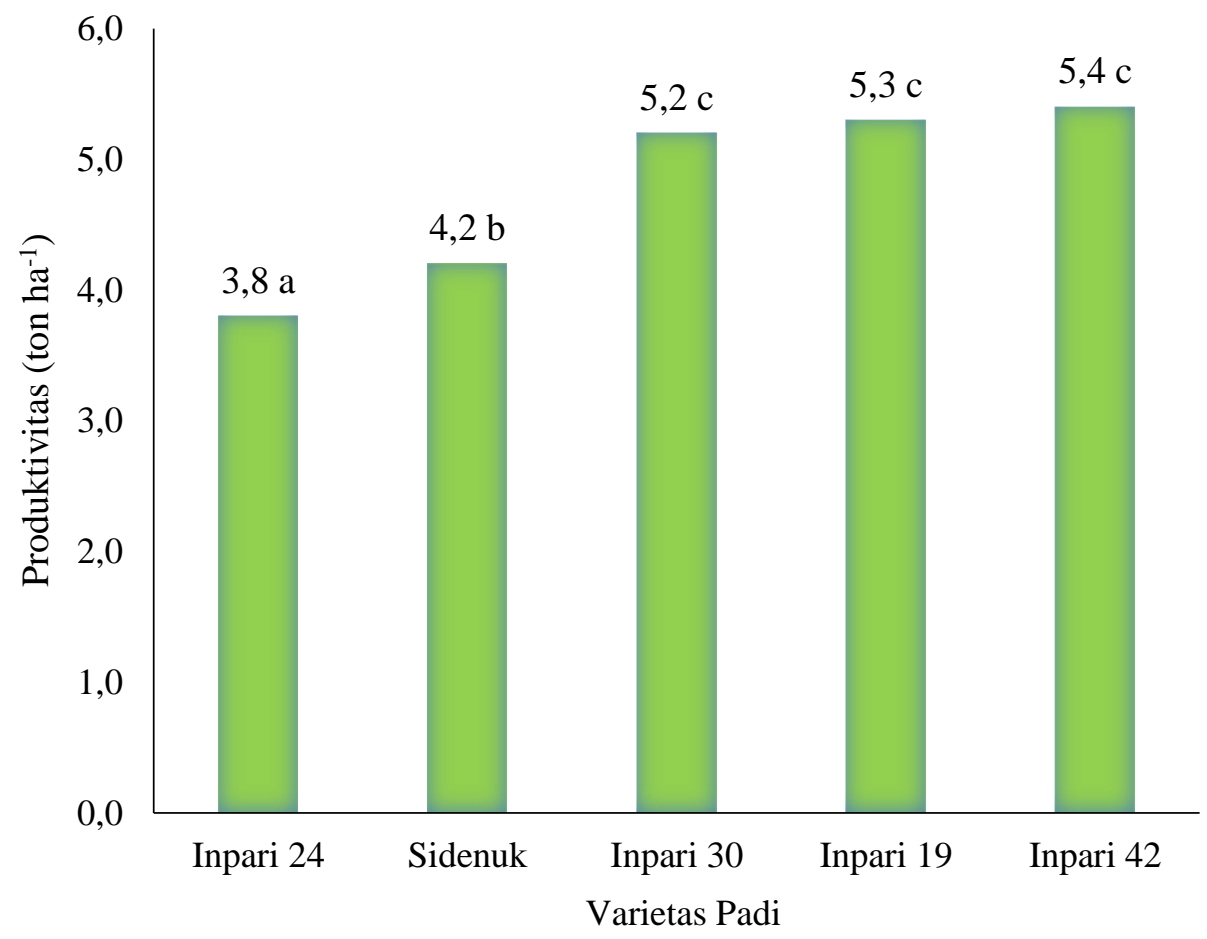

Gambar 2. Produktivitas padi pada musim tanam ke dua tahun 2019

Keterangan: *) Angka yang diikuti notasi huruf sama menunjukkan tidak berbeda nyata berdasarkan uji DMRT taraf 5\%

Petani memiliki persepsi yang beragam terkait dengan komponen teknologi untuk menunjang pertanaman padi pada musim tanam ke dua (Tabel 2). Petani setuju untuk menggunakan varietas unggul, benih padi bermutu dan berlabel, pengolahan tanah, persemaian, tanam bibit umur 15 hari, cara tanam jajar legowo dan pemupukan sesuai dosis, irigasi dan pemupukan organik.

Pengendalian hama dan penyakit secara terpadu tidak semua petani setuju. Petani banyak yang memilih aplikasi herbisida sebelum tanam karena lebih mudah, walaupun ada yang setuju pengendalian gulma secara mekanik. Petani setuju dengan pemupukan organik, namun keberatan apabila sesuai dosis karena keterbatasan sumber pupuk organik. Irigasi tambahan sesuai kebutuhan menjadi pertimbangan khusus petani karena memerlukan modal awal.

Secara umum pertimbangan pokok petani untuk menanam padi pada musim tanam ke dua mengandalkan irigasi pompa asal Bendung Sungai Oyo adalah terkait keterbatasan modal usaha tani, terutama terkait biaya penyiraman. Petani menerima, namun ada faktor pembatas berupa modal untuk biaya penyiraman. 
Tabel 2. Persepsi petani terhadap komponen teknologi peningkatan indeks pertanaman padi pada musim tanam ke dua

\begin{tabular}{|c|c|c|c|c|c|}
\hline \multirow{2}{*}{ Komponen teknologi } & Setuju & Kurang setuju & Tidak setuju & Tidak tahu & Keterangan \\
\hline & \multicolumn{4}{|c|}{ Persentase (\%) } & \\
\hline Varietas unggul & 100 & - & - & - & \\
\hline $\begin{array}{l}\text { Benih bermutu dan } \\
\text { berlabel }\end{array}$ & 100 & - & - & - & \\
\hline Pengolahan tanah & 100 & - & - & - & \\
\hline Persemaian & 100 & - & - & - & \\
\hline Tanam bibit umur 15 Hari & 100 & - & - & - & \\
\hline Cara tanam jajar legowo & 100 & - & - & - & \\
\hline Pemupukan sesuai dosis & 100 & - & - & - & \\
\hline $\begin{array}{l}\text { Pengendalian hama dan } \\
\text { penyakit terpadu }\end{array}$ & 40 & 25 & - & 35 & \\
\hline $\begin{array}{l}\text { Pengendalian gulma } \\
\text { terpadu }\end{array}$ & 25 & 35 & 50 & - & $\begin{array}{l}\text { Semprot sebelum } \\
\text { olah tanah }\end{array}$ \\
\hline Irigasi & 100 & - & - & - & \\
\hline $\begin{array}{l}\text { Irigasi tambahan sesuai } \\
\text { kebutuhan tanaman padi }\end{array}$ & 30 & 50 & - & 20 & Kurang modal \\
\hline Pemupukan organik & 100 & - & - & - & \\
\hline $\begin{array}{l}\text { Pemupukan organik sesuai } \\
\text { dosis }\end{array}$ & 10 & 40 & - & 50 & $\begin{array}{l}\text { Kekurangan pupuk } \\
\text { organik }\end{array}$ \\
\hline $\begin{array}{l}\text { Peningkatan indeks } \\
\text { pertanaman padi pada } \\
\text { musim tanam ke dua } \\
\text { dengan irigasi tambahan }\end{array}$ & 65 & 15 & - & 20 & Kurang modal \\
\hline
\end{tabular}

\section{KESIMPULAN}

Peningkatan produksi padi dapat dilakukan melalui peningkatan indeks pertanaman padi 1 menjadi 2 pada musim tanam ke dua memanfaatkan irigasi tambahan dari bendung sungai. Produktivitas varietas Inpari 42, Inpari 19 dan Inpari 30 tinggi. Varietas Inpari 19 prospektif dikembangkan karena memiliki produktivitas tinggi dan panen lebih cepat. Sebagian besar petani menerima komponen teknologi yang diterapkan, dengan modal untuk biaya penyiraman sebagai faktor pembatas.

\section{DAFTAR PUSTAKA}

Alimoeso, S. (2009). Program peningkatan produksi beras nasional (P2BN). Prosiding Seminar Nasional Padi. Buku 1. Balai Besar Penelitian Tanaman Padi. Badan Penelitian dan Pengembangan Pertanian. Departemen Pertanian.

Balai Penelitian Tanaman Padi. (2004). Inovasi teknologi untuk peningkatkan produksi padi dan kesejahteraan petani. Balai Penelitian Tanaman Padi - Pusat Penelitian dan
Pengembangan Tanaman Pangan - Badan Penelitian dan Pengembangan Pertanian

BPS - Badan Pusat Statistik Kabupaten Gunungkidul. (2018). Kabupaten Gunung Kidul dalam angka 2018. Tersedia dari https://gunungkidulkab.bps.go.id/publication/ 2018/08/16/e60b275962ba0b1eed798c16/kab upaten-gunung-kidul-dalam-angka-2018.html

Daradjat, A. A. (2001). Program pemuliaan partisipatif pada tanaman padi: Konsep dan Realisasi. Lokakarya dan Penyelarasan Perakitan Varietas Unggul Komoditas Hortikulura melalui Penerapan Program Shuttle Breeding. Jakarta.

Guswara, A., \& Samaullah, M. Y. (2009). Penampilan beberapa varietas unggul baru pada sistem pengelolaan tanaman dan sumberdaya terpadu di lahan sawah irigasi. Prosiding Seminar Nasional Padi 2008: Inovasi Teknologi Padi Mengantisipasi Perubahan Iklim Global Mendukung Ketahanan Pangan. Buku 2. Balai Besar Penelitian Tanaman Padi. Badan Penelitian Dan Pengembangan Pertanian. Departemen 
Pertanian. Tersedia dari http://www.litbang. pertanian.go.id/special/padi/bbpadi_2008_pro sb207.pdf

Hutajulu, H. F., Rosmayati, \& Ilyas, S. (2013). Pengujian respons pertumbuhan beberapa varietas padi sawah (Oryza sativa L.) akibat cekaman salinitas. Jurnal Agroekoteknologi Universitas Sumatera Utara, 1(4), 1101-1109. Tersedia dari https://jurnal.usu.ac.id/index.php /agroekoteknologi/article/view/4387

Las, I., Makarim, A. K., Sumarno, Purba, S., Mardiharini, M., \& Kartaatmadja, S. (1999). Pola IP Padi 300: konsepsi dan prospek implementasi sistem usaha tani berbasis sumberdaya. Badan Penelitian dan Pengembangan Pertanian. Jakarta. Tersedia dari https://scholar.google.com/scholar?cluste $\mathrm{r}=10384455677117907544 \& \mathrm{hl}=\mathrm{en} \& \mathrm{oi}=\mathrm{schol}$ arr

Las, I., Widiarta, I. N., \& Suprihatno, B. (2004). Perkembangan varietas dalam perpadian nasional. In Inovasi Pertanian Tanaman Pangan. Pusat Penelitian dan Pengembangan Tanaman Pangan. (pp. 1-25).

Makarim, A. K., Suhartatik, E., \& Kartohardjono, A. (2007). Silikon: Hara penting pada sistem produksi padi. Iptek Tanaman Pangan, 2(2), 196-204. Tersedia dari http://ejurnal.litbang. pertanian.go.id/index.php/ippan/article/view/2 659\#: :text=Silikon\%20(Si)\%20banyak\%20t erkandung\%20pada,\%2C\%20dan\%20gabah\% 20 (padi).\&text=Akibatnya $\% 2 \mathrm{C} \% 20$ hasil $\% 20$ optimal \%20tanaman\%20tidak,fluktuatif) $\% 20$ dan\%20mutu\%20produk\%20rendah.

Makarim, A. K., \& Las, I. (2004). Terobosan peningkatan produktivitas padi sawah irigasi melalui pengembangan model pengelolaan tanaman terpadu (PTT). Badan Litbang Pertanian. Jakarta. Tersedia dari https:// scholar.google.com/scholar?cluster $=5165777$ $346320812896 \& \mathrm{hl}=\mathrm{en} \& \mathrm{oi}=$ scholarr

Minarsih, A., Prayudi, B., \& Warsito, W. (2013). Keragaan beberapa varietas unggul baru padi sawah irigasi dengan menerapkan pengelolaan tanaman terpadu (PTT) di Kabupaten Klaten. Seminar Nasional: Menggagas Kebangkitan Komoditas Unggulan Lokal Pertanian dan Kelautan. Fakultas Pertanian Universitas Trunojoyo Madura - Balai Pengkajian Teknologi Pertanian Jawa Tengah. Hlm 582-587.

Nurhati, I., Ramdhaniati, S., \& Zuraida, N. (2008). Peranan dan dominasi varietas unggul baru dalam peningkatan produksi padi di Jawa Barat. Buletin Plasma Nutfah, 14(1), 8-13. Tersedia http://ejurnal.litbang.pertanian.go.id/ index.php/bpn/article/view/5088

Sadikin, S. (1985). Kedelai. Pusat Penelitian dan Pengembangan Tanaman Pangan, Bogor.

Saidah, Syafruddin, \& Pangestuti, R. (2015). Daya hasil padi sawah varietas Inpari 24 di beberapa lokasi SL-PTT di Sulawesi Tengah. Prosiding Seminar Nasional Masyarakat Biodiversitas Indonesia (Pros Sem Nas Masy Biodiv Indon), 1(5)1147-1150. Tersedia dari https://smujo.id/psnmbi/article/download/124 3/1210/

Soewito, T., Harahap, Z., \& Suwarno, S. (1995). Perbaikan varietas padi sawah mendukung pelestarian swasembada beras. Prosiding Simposium Penelitian Tanaman Pangan III. Tersedia dari https://scholar.google.co.id/ scholar?cluster $=15911163681740008500 \& \mathrm{hl}$ $=i d \& a s \_s d t=2005 \&$ sciodt $=0,5 \&$ scioq $=$ Perbai kan+varietas+padi+sawah+mendukung+peles tarian+swasembada+beras.+Prosiding+Simpo sium+Penelitian+Tanaman+Pangan+III

Suprihatno, B., Dradjat, A. A., Satoto, Baehaki, Widiarta, N., Setyono, A., Indrasari, S. D., Lesmana, O. S., \& Sembiring, H. (2007). Deskripsi varietas padi. Tersedia dari http://lampung.litbang.pertanian.go.id/ind/ima ges/stories/publikasi/deskripsipadi.pdf

Suyamto, R. Hidajat, S. Wahyuni, \& Samaullah, M. Y. (2007). Pedoman bercocok tanam padi. Badan Penelitian dan Pengembangan Pertanian. Departemen Pertanian 